\title{
How To Build Students' Characters Based on Child- Friendly Education (Collaboration Study of MAN 2 Yogyakarta with Ainul Yaqin Islamic Boarding School Gunungkidul)
}

\author{
Wahab $^{1}$, Mulyani Mudis Taruna ${ }^{2}$, Ahmad Muntakhib $^{3}$ \\ \{wahab.alba@gmail.com ${ }^{1}$, tarunamulyani@gmail.com², amuntakhib78@gmail.com ${ }^{3}$ \}
Reseacher at the Religious Research and Development Ministry of Relegious Affairs Semarang, Alumni of Semarang State University ${ }^{1}$
Reseacher at the Religious Research and Development Ministry of Relegious Affairs Semarang, Alumni of Yogyakarta State University ${ }^{2}$
Reseacher at the Religious Research and Development Ministry of Relegious Affairs Semarang, Alumni of Walisongo State Islamic University ${ }^{3}$

\begin{abstract}
There are two models to build students' characters, which are independence and collaboration. Independence is performed internally by the educational institution itself, while collaboration is done through "cooperating with" other institutions. MAN 2 Yogyakarta is an institution that has built the characters of its students in collaboration with Ainul Yakin Islamic boarding school Gunungkidul. The school applies independence model by creating "child-friendly" madrasa through habituation, and it runs without violence and punishment. Naughty students are considered the ones who have "more energy". If such students do not change better until grade XII, a "service" process is conducted. The collaboration model is conducted with the Ainul Yakin Islamic boarding school. This Islamic boarding school fosters students with special needs (disabilitied students) who have special potential for each individual student. This potential is the thing that puts the students at the level of 'ilmal yaqin, Ainul yaqin, or Haqqul yaqin, for Assisted Students, Assisted-Directed Students, and independent Students. The collaboration between the two institutions provides new hope for students who have "more energy" and disabled students to rise up and have independent characters.
\end{abstract}

Keywords: Independence, characters, collaboration, disabilitied, habituation

\section{Introduction}

Education of students' character today is always emphasized in formal education, even though students have attended formal education based on religion. Schools based on religion or madrassas characterized by religion do not guarantee that students have the character expected by parents and the nation. The unexpected character is reflected in the behavior of students, especially in the problem of delinquency because it in general is not only due to factors of association with outsiders, but also due to internal factors such as failure to find self-identity and difficulty controlling emotions. Even adolescents who become students from madrassas and schools based 
on religious organizations when failing in academic are easy to vent their emotions on negative things. Concrete examples are truancy, fights and brawls. This delinquency is found almost every day in the news in the capital city, big cities, and in small cities like Kendal. (Fuadah, 2011).

Different from students in formal educational institutions, those in Islamic boarding schools are more likely to have a measurable character from a religious perspective. Even some Islamic boarding schools specialize in education, not only strengthening the mastery of reading Arabic texts and mastery of the science of tools, but strengthening the aspects of morality and more elegant personal formation, such as the tasauf Nahdlotul Fata Demak Islamic boarding school in Central Java, the Istighfar Tombo Ati Islamic Boarding School especially for criminals in Semarang, and an islamic boarding school that specializes in education based on disabled students.

The disparity between common students and santris (students in islamic boarding schools) in behavior is a common thing because of different educational models, in terms of teaching materials and aspects of the teaching staff and the learning system being held. The disparity of the learning model with boarding will produce products with different characters from non-boarding. Likewise, teaching materials sourced from salafiyah books are different from textbooks. Character is the one that is more influental in shaping behavior. An islamic boarding school has a central figure, i.e. a Kyai who has an emotional relationship with students. Meanwhile, formal educational institutions do not have any influential figures and the relationship with students is only a relationship of learning interests.

The strength of madrasa/school in developing intelligence is done in a structured manner, so that students can master various knowledge. In addition, madrasa/school also strengthens education by building the character of students to be good. However, there are many students who strengthen their knowledge in madrasa/schools while building their own character at islamic boarding school, vice versa. Both of the models are quite common in various regions in Indonesia. This study tries more deeply to identify and examine the collaborative relationship between MAN 2 Yogyakarta and Ainul Yakin Islamic boarding school through a spiritual healing approach.

The formulations of the problems that are the focus of the study are: 1) what is the collaborative model for strengthening character education through spiritual healing?, 2) what is the collaboration strategy applied by MAN 2 Yogjakarta together with Ainul Yaqin Islamic boarding school, and 3) What factors support the collaboration process? This study aims to describe, analyze, and conclude a collaborative model of strengthening character education through spiritual healing, the collaboration strategy used by MAN 2 Yogyakarta with Ainul Yaqin Islamic boarding school, and the factors that support the collaboration process.

\section{Theoretical framework Adolescent Psychology}

Adolescence is the final phase of childhood and the beginning of the adult phase. Adolescence is betwee 10 and 21 years. There are many changes in adolescents, both physically and psychologically. Physical changes are seen in sexual changes such as breasts getting fuller and waist expanding in girls. The changes in boys are the mustache, beard and voice. This phase is a very important phase in further development. It is also known as the puberty phase. Adolescence is a certain period that every human being experiences before going on adulthood where children 
need a lot of guidance and direction from responsible parties, in order to provide a security and they are expected to develop well (Mukhlas, 2019, p.27).

Teenages really need peers to get to know the outside world. They often experience a variety of pressures in getting along with their peers. Various deviant actions often appear in this phase, these actions include committing trouble, stealing, fighting, bullying, and drug abuse. The circulation of positive and negative actions is a natural part of becoming an emotionally independent and sensitive adult (Diananda, 2019). In Increased knowledge of adolescents about cognitive development and psychological emotions in early adolescence, they begin to be able to think rationally and channel emotions in positive activities (Sary, 2017).

It is necessary to always study the development of adolescents because they are children of the times. They develop according to the times passed. Also, they are required to be able to develop all their potential in order to be able to pass adolescence with maturity. Furthermore, they are required to be able to adapt to the times with a solid foundation of faith, so that they do not fall into drugs and sexual freedom. They must be able to build awareness as God's best creatures . They are His representative in the world and are the hope of the nation and the State (Jannah, 2017). Solving adolescent problems requires a review by examining integrated and comprehensive knowledge (Fatmawaty, 2017).

Teachers' Discipline and correct understanding are that students' development is an important component in education (Elida \& Youth, 1991). Teachers' discipline is an example for his students because adolescent discipline and delinquency are closely related. The discipline is inversely correlated with juvenile delinquency. Adolescent discipline will enter into various aspects of their life, so the level of delinquency decreases or completely disappears (Rahmawati, 2017).

\section{Child-Friendly Education.}

Education should ideally be child-friendly. Child-friendly education is currently being promoted by inclusive education institutions. Inclusive education is the one that is friendly to all children, with an education service system that requires children with special needs to study at nearby schools in regular classes with their peers. The purpose of inclusive education is to fulfill the mandate of Article 31 of the 1945 Constitution, while what underlie inclusive education are philosophical, juridical, and empirical (Herawati, 2016).

Inclusive schools are the implementation of education without discrimination. All children receive the same education according to their respective needs. Inclusive education is a form of special education service that requires all children with special needs to receive an equal education in ordinary classes with their peers. So far, a special school has unwittingly built high walls for children with special needs. As a result of this system, children with special needs are difficult for society to accept. The implementation of inclusive schools for children with special needs must create an environment that is fun, friendly and can foster self-confidence for students with special needs. In fact, the implementation of inclusive schools in Indonesia is still not in accordance with the concept put forward and the implementation guidelines, in terms of students, teacher qualifications, facilities and infrastructure, and support from parents and the community. The implementation of inclusive schools in Indonesia is still a phenomenon (Darma \& Rusyidi, 2015). 
Children studying in child-friendly schools will feel happy. Their potentials will be explored and developed accordingly. Child-friendly schools use a learning model that prioritizes student activities. The school provides an environment and facilities that accommodate the needs of students so that they learn the materials they really need. Students are given the opportunity to convey their ideas, display their work, and participate in maintaining school facilities. By paying attention to these, it will be possible to produce quality graduates. Thus, child-friendly schools are a basic requirement in the development of basic education (Sudirjo, 2016).

Inclusive education is a special education service system that requires all children with special needs to be served in the closest school in the normal class together with their peers. the implementation of inclusive education for children with special needs should be able to create an environment that is friendly, fun, flexible, and able to foster self-confidence in students and educators with special abilities. In reality, the implementation has not all been in accordance with the guidelines, from the student's condition, teacher qualifications, supporting infrastructure, parental support, and support from the central and regional governments. Basically, the implementation of inclusive education for children with special needs is still a phenomenon (Praptiningrum., 2010).

Child-friendly schools are formal and informal education units that are safe, clean and healthy, care and have an environmental culture, are able to guarantee, fulfill, respect children's rights and protect children from violence, discrimination and other mistreatment, and support participation especially in planning, policies, learning, monitoring, and complaint mechanisms related to the fulfillment of children's rights and protection in education. Child-friendly schools are not making new buildings but a new paradigm in educating and teaching students to create a new generation that is strong without violence, fosters adult sensitivity in educational units to fulfill rights, and protects students.

Child-Friendly Schools can be established if supported by various parties including the family and the community that are actually the closest educational centers for children. A supportive, protective environment that provides a sense of security and comfort for children will greatly assist the process of finding identity. Children's habits have a tendency to imitate, try, and seek recognition of their existence in the environment in which they live. The family environment is the first and foremost education for children so that the family plays a role as economic protection and provide space for expression and creativity. Child-friendly education components include: First is child-friendly education policies. Second is educators and education staff who understand children's rights. Third is the implementation of a child-friendly learning process with the application of discipline without violence. Fourth is facilities and infrastructure that do not endanger children, and prevent children from getting hurt. Fifth is children's participation: Children's participation includes: communicating school programs by involving children (Yosada \& Kurniati, 2019).

\section{Literature review}

Research on strengthening the education of students' characters has been widely conducted. Likewise, research related to spiritual healing has been done by several previous researchers. Several of these studies are as follows. 
1. Research conducted by Ngatiman and Ibrahim, that character education is to form a personality whose results are expected to create students to have good behavior, honesty, responsibility, respect for others, and hard work. This study identifies character education with moral education in Islam in order to able to transfer values into the soul and manifest in action (Ngatiman \& Ibrahim, 2018).

2. Research conducted by Zain Irwanto with the title "Aggressive behavior and how to handle it through Islamic counseling" from the Islamic religious faculty of the Muslim University of Indonesia shows that the application of Islamic counseling to the problem of students behaving aggressively shows a change in the behavior of students to be not aggressive. Research focused on students of SMPN 1 Tondong Tallasa Pangkep also emphasizes that the factors that cause aggressive behavior are arrogant, selfish, family economy, family environment (Irwanto, 2017)

\section{Methods}

This study used a qualitative descriptive approach, which is a research approach that seeks to capture the symptoms actually occuring and experienced by the research subject. These phenomena can be in the form of views, attitudes, behaviors, and so on in the form of words and language collected holistically using scientific methods (Moeleong, in Wahab, 2015: 40). Creswel, in Sugiyono (2013: 347-348) explains that qualitative research is a research activity that departs from temporary questions to collect field data related to perceptions, actions, and so on towards individuals and social groups (humans). and then interpreted the meaning of a data.

The qualitative approach in this study was a case study model, carried out on two educational institutions i.e. MAN 2 Yogyakarta and Ainul Yakin Islamic Boarding School Gunungkidul. The research process at the two institutions was carried out in an accountable, honest, careful, and in-depth manner in the case of education and/or character building for the "more energy" students of MAN 2 Yogyakarta City and inclusive Santris at Ainul Yakin Islamic Boarding School, Gunung Kidul.

Data collection techniques were done through interview, observation, focus group discussion (FGD), and document study. Interviews were conducted using open-ended method and focused on uncovering data related to the facts of students with "more energy" in MAN 2 Yogyakarta and the implementation of education at Ainul Yakin Islamic Boarding School, Gunungkidul. Through these open-ended interviews, it was possible for the informants to convey their own views regarding the facts as they were. Interviewing was focused in this case to reveal (review) data in a relatively short time and was not tied to structured interview guidelines. Observation was used to observe and record the phenomena studied systematically and relevantly to the problem. The data in this study, among others, were related to the students of MAN 2 Yogyakarta included in the category of "more energy", the criteria for students with "more energy", the procedures and processes of students being declared to have "more energy", time of education/coaching at Ainul Yakin Islamic Boarding School, material and therapeutic methods, and so on.

To corroborate the results of interviews and observations, FGD was conducted between the Head of MAN 2 and the guidance and counseling teacher at MAN 2 Yogyakarta, while FGD in Ainul Yakin Islamic Boarding School was conducted by the Head of the school with its manager and Committee.In addition, data triangulation was also carried out by various parties that have a relationship between MAN 2 Yogyakarta and Ainul Yakin Islamic Boarding School 
Gunungkidul. The document review technique was used to reveal the data recorded in books, minutes, transcripts, files, meeting results, and so on. The relevance of the document technique in this study was to collect data, such as: the number of "more energy" students, the results of the decision on the "more energy" session, the research of students included to have "more energy", the coaching/therapy curriculum towards "more energy" students, schedule of therapy activities, number of therapists, etc. There were two kinds of data sources in this study,which were primary and secondary. The primary data sources came from the Head, Deputy Student Affairs, and Counseling Teacher of MAN 2 Yogyakarta, boarding school leader, therapists, instructors, students/santris). Meanwhile, secondary data came from the Boarding School Committee, community members, documents, WEB.

This study used analysis data developed by Miles and Huberman as quoted by Sugiyono (2013: 404), which is interactive and continues to completion, so that the data was saturated. Miles and Huberman in Wahab (2017: 6-7) explain that the analysis is done in two stages, namely during the field and after the field. In the field analysis, there are several steps, including: (1) narrowing the focus of the study to spesify the scope of research and limit the data collected, (2) determining the type of study, (3) developing analytic questions, and (4) composing comments. Meanwhile, the following steps from the field are: (1) making categorizations of findings and (2) arranging the sequences of the studies. To sum up, the qualitative data analysis has three stages, i.e. data reduction, data presentation, and drawing conclusions.

\section{Finding And Discussion}

Strengthening character education of students in MAN 2 Yogyakarta City used 2 models, namely internal strengthening of madrasa and strengthening through external madrasa institutions. Internal strengthening was to be familiar with the jargon of Madrassas as child-friendly madrassas, while external strengthening was to collaborate with Ainul Yakin Islamic Boarding Schools which have historical roots and emotional bonds with MAN 2 Yogyakarta. The two models used by MAN 2 Kota Yogjakarta provide new atmosphere in formal education to build students who have high learning enthusiasm and good togetherness ethos.

Institutionally, MAN 2 Yogyakarta and Ainul Yakin islamic boarding school do not have a formal cooperative relationship and each has a different "learner" segmentation. MAN 2 Yogjakarta only accepts students who have graduated from madrasa/junior high school, while Ainul Yakin Islamic Boarding School accepts all students regardless of age and educational background.

\section{Development of Character Education in MAN 2 Yogyakarta}

Internal character strengthening is creating students' habituation in accordance with the vision and mission of the madrasa. It has been implemented by MAN 2 Yogyakarta Yogyakarta since its establishment in 1978, which has religious characteristics. The madrasa, located at Jalan KHA. Dahlan 130 Yogyakarta (55261), has a vision of Taqwa, Independent, Achievement, Innovative, Environmentally Friendly, and Islamic. This vision is better known as the ISLAMIC LOOK vision. Missions of MAN 2 Yogjakarta are: a) Realizing Madrasa people who are knowledgeable, charitable, and have a noble personality (good manners), b) Realizing Madrasa people who master science and technology, language, culture, sports and arts, c). Creating a madrasa that is globally competitive, and d) Creating a conducive and Islamic madrasa 
environment. The general objectives include; a) Realization of Madrasa people who practice the values and teachings of Islam in everyday life, b) The realization of smart, skilled, independent students to continue their education, c) The realization of a high work culture in providing excellent educational services, d) Realization of madrasa that provides wide access, accountability, and dignity, e) Realization of Madrasa personnels who are proficient in information technology and foreign languages, f) Realization of a clean, healthy, orderly, comfortable, safe, and Islamic environment and atmosphere of the madrasa, g) Integrated insights.

MAN 2 Yogyakarta city has the jargon as a "Child-Friendly" madrasa. The simple thing with the child-friendly concept is that all activities and learning processes are based on fostering and educating in line with positive thinking. According to its Head and guidance and counceling teacher, the dynamics of learning and education run without violence but with togetherness. Building a natural environment in a comfortable madrasa is also followed by a dynamic and fun learning environment. The madrasa never punishes its students nor recognizes violation point. Punishment for student violations is up to the student himself, and at a certain level it is given to his parents by conducting a case conference among the student, his parents, his homeroom teacher, the head, and guidance and counceling teacher.

The principle of no punishment for students does not mean that no one violates the rules or regulations of the madrasa. If any student still does violations, he or she is considered to have "more energy". According to the Madrasa Head, the madrasa also applies a system of a homeroom teacher who is assigned from grade X to the end of grade XII. Thus, the homeroom teacher can understand the character of students as long as they study there.

\section{Spiritual Healing for Santris at Ponpes Ainul Yakin Islamic Boarding School}

The term of spiritual healing is actually to facilitate the process of coaching students with a disability. This coaching process is directly led by Isma Teacher or Isma Almatin Teacher or Muhidin Isma Al Matin teacher,commonly called Abi Guru. He is a religious preacher, book writer, inspirational motivational trainer, child development consultant, or expert therapist for children with special needs. Isma teacher is an alumnus of MAN 2 Yogjakarta who did not get a diploma even though he attended school for up to 4 years. The certificate was obtained from the Package $\mathrm{C}$ program to continue to private universities in Yogjakarta.

It is challennging that disabled students are chosen to be the subject of guidance at Ainul Yakin Islamic Boarding School. The motto "Loving Problems" and believing that the most important thing in life is prayer opens the possible success in fostering the students. The life concept is just waiting for prayer and while waiting for prayer time, there many activities to do, such as working, studying, doing other positive activities. It will result in optimizing the disabled students' potential. The belief in the success of this concept was manifested by establishing a Correctional Center for Children with Special Needs for Indonesia in Karang Tengah, Sumber Wungu Tepus, Gunungkidul, Yogyakarta on January 26, 2018. This correctional center exists as an inclusion school with therapy area facilities (farming therapy farming, fishing therapy), outbound, swimming pool, gazebo, hall, and foot reflexology.

The main goal of Ainul Yakin Islamic Boarding School is to build a civilization for disabled children that will spread throughout Indonesia by having the advantage of specialists in education, assessment, and correctional services for children with special Islamic needs, and who memorize Al Quran Hadith. The general objectives are as follows; 
1. Santris (its students) can become perfect, noble, and good beings as Allah mentions in the Al Quran, and when they return home, they become children who are diligent in worshiping Allah SWT according to Allah's purpose for creating humans to worship. God willing, if they are diligent and have true worship, they will have their lives fulfilled by Allah and will become lucky creatures.

2. Santris become children who are confident, mentally good, and visionary.

3. Santris get the doctrine to always be people who like to do charity/good deeds and are devoted to their parents, are able to speak Arabic, English, memorize the Qur'an hadiths, understand fiqh, and have correct morals.

The Isma Teacher who is the author of the book "Hypnoword Magic" and has been a trauma healing trainer in Aceh after tsunami focuses on fostering disabled children as special santris (Special Children City), each of whom has his own competence and potential to be developed and is in defined categories such as Assisted Santris, Assissted-directed Santris, and Independent Santris. To determine those caegories, observation is done for 40 days by Isman teacher once their parents entrust them. During the observation, monitoring and guidance are performed on the level of intelligence (cognitive), attitude/behavior (affective), and aspects of action or physical movement (psychomotor). From the results, they are assigned to the category Assisted Santri (AS), Assisted-Directed Santri (ADS), or Independent Santri. The decision is not negotiable to the parents who have entrusted them.

Conceptually, the three categories are as follows.

1. Assisted Santris are disabled students who cannot do activities perfectly. This concept is that these santris are perfect because they have no responsibility because of their limited sense and noble students who can become part of a family where their parents must perceive them that Allah creates humans with the best of creations. The target of the assisted students is that as optimal as possible the students can pronounce anything, such as the word Aamiin or the pronunciation of miin or even only with the movement of the limbs that are moved as a sense of being able to do something with movement.

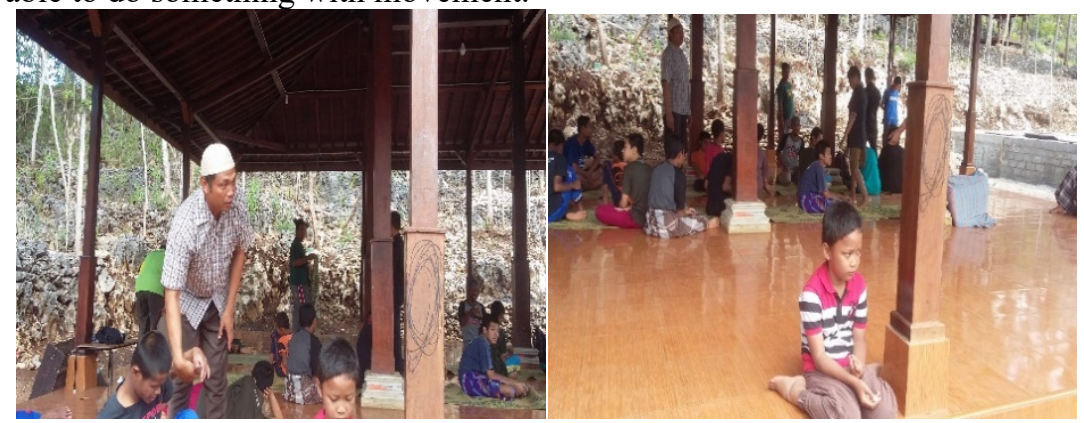

Terapi santri bantu oleh santri arahan yang diinstrukturi oleh terapis The assisted santri therapy by assisted-directed-santri therapy instructed by the therapist

2. Assisted-Directed Santris are professional ones who have the type of worker but are unable to manage. These santris are targeted to become students who have the ability as professional workers 


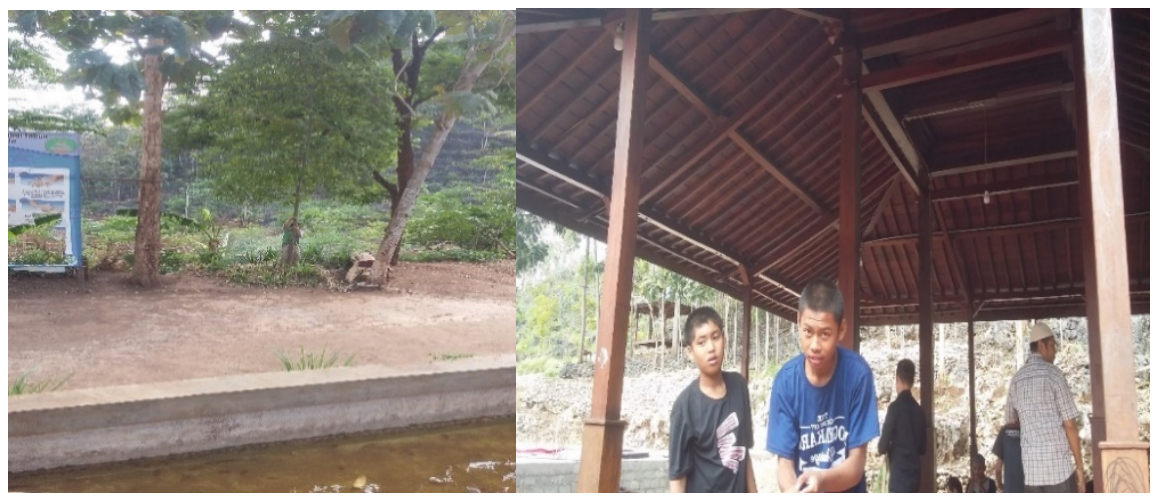

Santri Arahan habis naik pohon dan santri arahan habis membantu memberi terapi terhadap santri bantu Assisted-directed santris finish climbing a tree and help provide therapy for the assisted santris

3. Independent Santris are students who are able to manage and direct the assisted-directed students and the assisted students. They are not students who have a concept but have responsibility for the tasks to do.

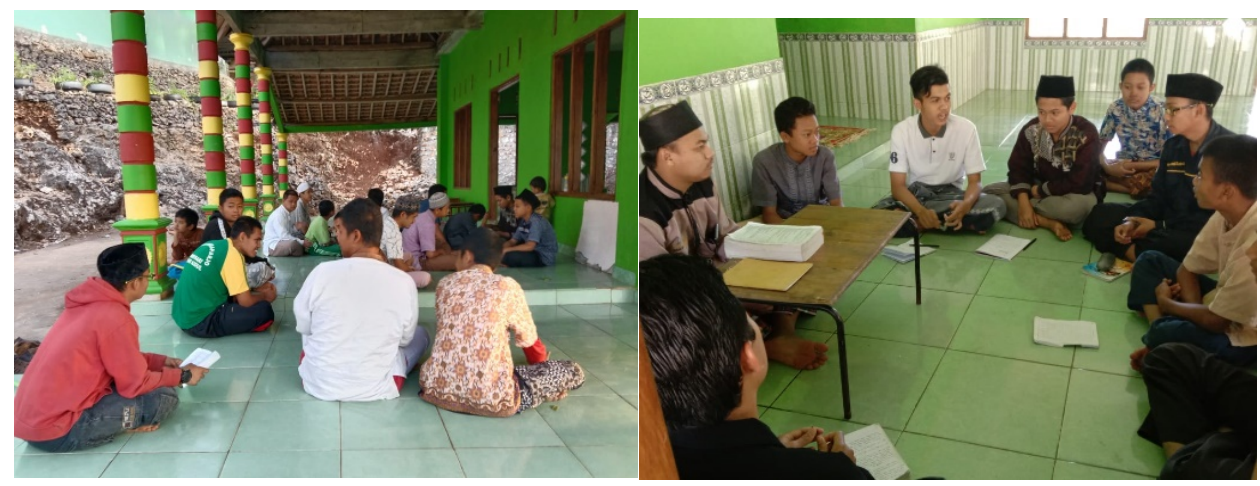

Independent Santris learn to memorize the al-Qur'an, guided directly by the instructor (above) and murojaah and recitation of al-Qur'an memorization

\section{Collaborative Model for Character Education Strengthening through Spiritual Healing}

MAN 2 Yogyakarta City and Ainul Yakin Gunungkidul islamic boarding scool have an emotional closeness, where Isman Teacher as the founder of the Ainul Yakin Islamic Boarding School is an alumnus of MAN 2 Yogyakarta. It facilitates the collaboration between them. Formally there is no $\mathrm{MoU}$ as a collaborative step, but the bond between the two institutions is so strong that the collaboration happened. Also, MAN 2 collaborates with Muhammadiyah Lowano Boys Orphanage to guide students who have"more energy".

The collaboration between MAN 2 Yogyakarta and Ainul Yakin islamic Boarding School is not only for students who have "more energy", but also for grade XII students who will have the national final exam. In order that students are completely ready to face both madrasa and national 
final exams, motivation training is conducted. As for students who have "excess energy", there are several stages, as follows:

1. MAN 2 Yogyakarta has developed a guardianship strategy that runs as long as students learn from grade X - XII by the same homeroom teacher. The continuing model has advantages, i.e.1) the homeroom has complete data about the student (track record) so that if the student makes a mistake it is easy to complete, 2) the homeroom teacher can cooperate with counseling teachers to provide guidance to students who have "more energy", there is no "jealousy" among the teaching staff about mementos given to grade XII teachers.

2. MAN 2 Yogyakarta firstly holds a case conference attended by students' parents, students, counseling teacher, homeroom teacher, and principal of the madrasa because students have moved up to grade XII but there has been no change in behavior. The case conference results in two options i.e. the students are directly fostered by their own parents or by Ainul Yakin Islamic boarding school. If they are decided to be fostered at Ainul Yakin Islamic Boarding School, the madrasa and their parents prepare "ubo rampai" to go to the Islamic boarding school. This coaching activity was once conducted on October 9-14, 2019 on behalf of Hadid Nurul Ikhsan (grade XII IIK) and Awang Nurardianto (grade XII IBB) at Ainul Yakin Islamic Boarding School Tepus Gunungkidul.

3. The students are sent to conduct community services at Ainul Yakin Islamic Boarding School for at least 1 week (7 days) and if they have not changed their attitude and character, it can be extended. However, so far, one week is enough to build the character of students to have a good learning spirit and responsibility.

4. Ainul Yakin Islamic Boarding School is cared for by Ismanto (Isman Teacher), an alumnus of MAN 2 Yogyakarta majoring in language. Therefore, Ainul Yakin Islamic Boarding School and MAN 2 Yogyakarta have an emotional bond between them. Ismanto was a student who hd a "free" character because he is an artist. Ismanto's works are well known in the form of poetry (several are published in a book called Hypnoword Magic; Mantra-mantra Pikiran Bawah Sadar) and theater.

5. The notification letter regarding this coaching declares that the student is carrying out community service as a coach of the Madrasa based on the decision of the case conference. It is not the student who is being guided because of punishment, but is the one who is carrying out services that will generate empathy for disabled students.

\section{Supporting factors for the collaboration process}

The MAN 2 Yogyakarta has succeeded in the collaboration with Pondok Pesantren Ainul Yakin Islamic Boarding School, Gunungkidul due to the strong support from both of the parties. Isma teacher who has studied at MAN 2 Yogyakarta feels that he has a long unforgettable history (4 years). MAN 2 Yogyakarta city gave "flexibility" to him when studying there to develop creativity. This was strongly supported by Mrs. Anita (language teacher) in every time he developd and displayed his creative results. Meanwhile, MAN 2 Yogyakarta feels that Ismanto was a very potential student, so it is necessary to keep providing assistance even though according to Mrs. Anita she felt that she failed in fighting for Ismanto to have a MAN 2 Yogyakarta diploma and only succeeded in supporting himto join the package $\mathrm{C}$ program. 
The historical factor of the emotional bond between the two parties becomes the main supporting factor for successful collaboration. This historical factor is also supported by several other factors, as follows:

1. Psychologically, Isma teacher is someone who understands and has therapeutic skills for adolescents with problems and has become a motivator in various activities related to recovery such as healing therapy in Aceh Post Tsunami. This understanding and experience are able to provide stimulus to MAN 2 students who have "more energy" to participate in the service at Ainul Yakin Islamic Boarding School.

2. The "child-friendly" education created by MAN 2 Yogyakarta provides its own "energy" for Isma teachers, so that it can be used as provisions for them to implement the same methods at Ainul Yakin Islamic Boarding School.

3. Students who are entrusted to Ainul Yakin Islamic Boarding School are those who have "more energy" which is still better than that of the students of Ainul Yakin Islamic Boarding School who have special needs, so that the model of coaching carried out by Isma teacher to MAN 2 students creates a strong sense of empathy to make MAN 2 students aware that they have not only "more energy" but also good ability and intelligence.

4. The application of the life concept about waiting for prayer time and doing various activities while waiting for it to strengthen the potential of each individual has become a "doctrine" of santris and students. This concept eventually becomes a strong supporting factor that appears in each individual.

\section{Conclusion}

MAN 2 Yogyakarta has two models to strengthen character education, i.e. internal madrasa and external madrasa. Strengthening through internal madrasa is to create child-friendly madrassas and habituation, while external madrasa is to collaborate with Ainul Yakin Islamic Boarding School, Gunungkidul. Child-friendly Madrasa creates a learning and educational process that runs with no violence nor punishment but with togetherness. Therefore, students who commit violation are considered to have "more energy". Likewise, Ainul Yakin Islamic Boarding School that disabled santris has a special potential in each of its individual to be optimized. This potential is the thing that puts all the santris at the level of 'ilmal yaqin, Ainul yaqin, or Haqqul yaqin.

The Collaboration Model of Strengthening Character Education in MAN 2 Yogyakarta and Ainul Yakin islamic Boarding School Gunungkidul is conducted without a formal MoU but through an emotional bond because the Head of Ainul Yakin islamic Boarding School is the alumnus of MAN 2 Yogyakarta. The technical implementation of the collaboration is that if there are MAN 2 students who have "more energy" in grade XII but have not changed, a "service" process will be conducted at Ainul Yakin Islamic Boarding School for 1 week so that when they return to Madrasa, they are ready to take the Madrasa and national exams. Additionally, grade XII students who need reinforcement for motivation, motivation training is also conducted at Ainul Yakin Islamic Boarding School.

It is important to keep the success of a symbiosis of mutualism between MAN 2 Yogyakarta and Ainul Yakin Islamic Boarding School. However, Ainul Yakin Islamic Boarding School as an inclusive institution needs to have formal legitimacy from the Ministry of Religion as a government institution. Thus, such a collaboration can be implemented not only with MAN 2 
Yogjakarta but also with other madrassas, both public and private ones. Even it can collaborate with the Ministry of Religious Affairs in various activities.

\section{References}

[1] Creswel, dalam Sugiyono, 2013. Metode Penelitian Manajemen, Pendekatan: Kuantitatif, Kualitatif, Kombinasi (Mixed Methode), Penelitian Tindakan (Action Research), dan Penelitaian Evaluasi, Bandung, Alfabeta.

[2] Darma, I. P., \& Rusyidi, B. (2015). Pelaksanaan Sekolah Inklusi Di Indonesia. Prosiding Penelitian Dan Pengabdian Kepada Masyarakat. https://doi.org/10.24198/jppm.v2i2.13530

[3] Diananda, A. (2019). Psikologi Remaja Dan Permasalahannya. Journal Istighna. https://doi.org/10.33853/istighna.v1i1.20

[4] Elida, P., \& Remaja, P. P. (1991). Perkembangan Peserta Didik. Dirjen Dikti: Jakarta.

[5] Fatmawaty, R. (2017). Memahami Psikologi Remaja. Jurnal Reforma. https://doi.org/10.30736 /rfma.v6i2.33

[6] Fuadah, N. (2011). Gambaran Kenakalan Siswa di SMA Muhammadiyah 4 Kendal. Jurnal Psikologi.

[7] Herawati, N. I. (2016). Pendidikan Inklusif. EduHumaniora| Jurnal Pendidikan Dasar Kampus Cibiru. https://doi.org/10.17509/eh.v2i1.2755

[8] Irwanto, Z. (2017). Perilaku agresif dan penangananya melalui konseling islami. Jurnal Pendidikan Dan Konseling, 3(pendidikan), 26-34.

[9] Jannah, M. (2017). Remaja Dan Tugas-Tugas Perkembangannya Dalam Islam. Psikoislamedia : Jurnal Psikologi. https://doi.org/10.22373/psikoislamedia.v1i1.1493

[10] Moeleong, dalam Wahab, 2015. Internalisasi Nilai-nilai Karakter Bangsa Melalui Pendidikan Agama Islam (PAI) pada Peserta Didik SMA, Semarang, PT. Pustaka Rizki Putra.

[11] Mukhlas, M. (2019). Aktualisasi Konsep Pendidikan Akhlak Al-Ghazali dalam Pembinaan Remaja. Journal of Chemical Information and Modeling, 53(9), 1689-1699. https://doi.org/10.1017/CBO9781107415324.004

[12] Ngatiman, N., \& Ibrahim, R. (2018). Pendidikan Karakter Dalam Perspektif Pendidikan Islam. Manarul Qur'an: Jurnal Ilmiah Studi Islam. https://doi.org/10.32699/mq.v18i2.949

[13] Praptiningrum. (2010). Fenomena penyelenggaraan pendidikan inklusif bagi anak berkebutuhan khusus. Jurnal Pendidikan Khusus.

[14] Rahmawati, N. (2017). Kenakalan Remaja Dan Kedisiplinan: Perspektif Psikologi dan Islam. Sawwa: Jurnal Studi Gender. https://doi.org/10.21580/sa.v11i2.1458

[15] Sary, Y. N. E. (2017). Perkembangan kognitif dan emosi psikologi masa remaja awal. Jurnal Pengabdian Kepada Masyarakat.

[16] Sudirjo, E. (2016). Model Pembelajaran Inovatif Berbasis Konsep Sekolah Ramah Anak. EduHumaniora | Jurnal Pendidikan Dasar Kampus Cibiru. https://doi.org/10.17509 /eh.v2i1.2748

[17] Yosada, K. R., \& Kurniati, A. (2019). Menciptakan Sekolah Ramah Anak. Jurnal Pendidikan Dasar Perkhasa: Jurnal Penelitian Pendidikan Dasar. https://doi.org/10.31932 /jpdp.v5i2.480 